2003s-45

\title{
Compensation Policy and Worker Performance: Identifying Incentive Effects from Field Experiments
}

\author{
Bruce Shearer
}

\begin{tabular}{c}
\hline Série Scientifique \\
Scientific Series
\end{tabular}

Montréal

Août 2003

(C) 2003 Bruce Shearer. Tous droits réservés. All rights reserved. Reproduction partielle permise avec citation du document source, incluant la notice $\odot$.

Short sections may be quoted without explicit permission, if full credit, including $\odot$ notice, is given to the source.
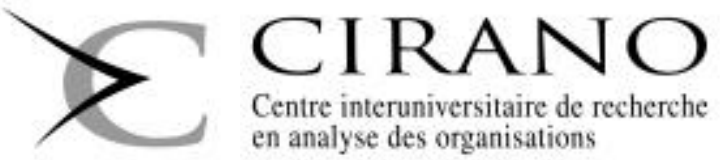

en analyse des organisations 


\section{CIRANO}

Le CIRANO est un organisme sans but lucratif constitué en vertu de la Loi des compagnies du Québec. Le financement de son infrastructure et de ses activités de recherche provient des cotisations de ses organisationsmembres, d'une subvention d'infrastructure du ministère de la Recherche, de la Science et de la Technologie, de même que des subventions et mandats obtenus par ses équipes de recherche.

CIRANO is a private non-profit organization incorporated under the Québec Companies Act. Its infrastructure and research activities are funded through fees paid by member organizations, an infrastructure grant from the Ministère de la Recherche, de la Science et de la Technologie, and grants and research mandates obtained by its research teams.

Les organisations-partenaires / The Partner Organizations

PARTENAire Majeur

. Ministère du développement économique et régional [MDER]

PARTENAIRES

. Alcan inc.

. Axa Canada

. Banque du Canada

. Banque Laurentienne du Canada

. Banque Nationale du Canada

. Banque Royale du Canada

. Bell Canada

. Bombardier

. Bourse de Montréal

. Développement des ressources humaines Canada [DRHC]

. Fédération des caisses Desjardins du Québec

- Gaz Métropolitain

. Hydro-Québec

. Industrie Canada

. Ministère des Finances [MF]

. Pratt \& Whitney Canada Inc.

. Raymond Chabot Grant Thornton

. Ville de Montréal

. École Polytechnique de Montréal

. HEC Montréal

. Université Concordia

. Université de Montréal

. Université du Québec à Montréal

. Université Laval

. Université McGill

AsSOCIÉ À :

. Institut de Finance Mathématique de Montréal (IFM ${ }^{2}$ )

. Laboratoires universitaires Bell Canada

. Réseau de calcul et de modélisation mathématique $\left[\mathrm{RCM}^{2}\right]$

. Réseau de centres d'excellence MITACS (Les mathématiques des technologies de l'information et des systèmes complexes)

Les cahiers de la série scientifique (CS) visent à rendre accessibles des résultats de recherche effectuée au CIRANO afin de susciter échanges et commentaires. Ces cahiers sont écrits dans le style des publications scientifiques. Les idées et les opinions émises sont sous l'unique responsabilité des auteurs et ne représentent pas nécessairement les positions du CIRANO ou de ses partenaires.

This paper presents research carried out at CIRANO and aims at encouraging discussion and comment. The observations and viewpoints expressed are the sole responsibility of the authors. They do not necessarily represent positions of CIRANO or its partners.

ISSN 1198-8177 


\title{
Compensation Policy and Worker Performance: Identifying Incentive Effects from Field Experiments*
}

\author{
Bruce Shearer ${ }^{\dagger}$
}

\begin{abstract}
Résumé / Abstract
L'utilité des expériences sur le terrain afin d'évaluer l'effet de différents systèmes de compensation sur la productivité des travailleurs est investiguée. Une attention particulière est portée à la capacité des expériences didentifier leffet d'un changement permanent de la politique de lentreprise. Bien que les expériences résolvent le problème d’endogénéité en permettant aux sujets d'être alloués à un système de compensation par un processus aléatoire, ceci est accompli dans un environnement spécifique et, à la fois, artificiel, qui ne saurait être répliqué par un changement permanent. Comme tel, plutôt que d'identifier l'effet incitatif sans restriction, les expériences nous fournissent la variation exogène qui permet d'identifier des paramètres structurels. Ces paramètres nous permettent d'évaluer les effets des changements de politiques de l'entreprise.
\end{abstract}

Mots clés : Économétrie des contrats, incitations, expériences.

The role of field experiments in evaluating the effect of compensation policies on worker productivity is considered. Particular attention is paid to the ability of a field experiment to identify the effect of a permanent change in firm policy. While field experiments solve endogeneity problems through randomization, they do so within a specific, and at times artificial, environment that may not be replicated by a permanent policy change. As such, rather than providing a basis for the unrestricted identification of incentive effects, experiments are better thought of as providing exogenous variation with which to identify structural parameters. These parameters can, in turn, be used to predict the effects of policy changes.

Keywords: Econometrics of Contracts, Incentives, Experiments.

Codes JEL : J3, L2, C9

\footnotetext{
* I acknowledge research support from FCAR, SSHRC and the Canadian Research Chair in Social Policies and Human Resources at the Université Laval. I thank Chris Ferrall for helpful comments.

† Département d'économique, Université Laval, CIRPÉE and CIRANO, Québec, Québec, G1K 7P4, Canada, email: Bruce.Shearer@Ecn.ULlaval.ca, tel. (418) 656-2131(\#5606), fax (418) 656-7798.
} 


\section{Introduction}

Economic theorists have extensively studied the importance of contracts under asymmetric information (see, for example, Hart and Holmstrom, 1987, Salanié 1994, Macho-Stadler and Pérez-Castrillo 2001). Within the field of labour economics much attention has focused on the nature of optimal contracts between firms and workers (for example, Lazear 1986, and Gibbons 1987). These models stress the importance of contractual form as a determinant of worker and firm performance. Many researchers have, therefore, examined the empirical relevance of agency models by testing for the presence of such incentive effects (see, for example, Ehrenberg 1990 and the papers contained therein). The ability of contracts to affect worker performance also takes on policy dimensions both at the firm level, where managers may want to evaluate the benefits of different policies (Milgrom and Roberts 1992, Lazear 1998), and at the macroeconomic level, where some economists (notably Blinder 1990) have highlighted the benefits of a widespread adoption of performance-pay compensation systems.

Empirical work on labour-market contracts ${ }^{1}$ has focused attention on comparing worker performance under different compensation systems; notably piece rates and fixed wages. One approach, typified by the work of Pencavel (1977), Seiler (1984), Brown (1992) and Parent (1999) compares worker wages under piece rates and fixed wages. These studies find wage premiums for piece rate workers that are consistent with the presence of incentive effects; namely, if piece rates raise worker productivity, piece-rate workers will be paid more. However, identification problems exist due to competing explanations of the data - wage premiums may reflect risk or selection effects. An alternative approach is to gather firm-level data providing information on contracts and worker performance. Variation in incentives embodied within the observed contracts can then be exploited to identify the effect of contracts on worker (and firm) performance. Examples include Ferrall and Shearer (1999), Paarsch and Shearer (1999 and 2000), Lazear (2000), Haley (forthcoming) as well as Copeland and Monet (2002).

Of particular concern in the measurement of incentive effects is the possible endogeneity of the contract. Since observed compensation systems represent choices made by the firm, if factors which are unobservable to the econometrician affect both the firm's choice and worker productivity, then simple comparisons of worker performance under different contracts will fail to identify the incentive effect.

Perhaps the most direct method of controlling for endogenous choice in empirical work is to perform field experiments. Such experiments have a long history of use in evaluating company policies. Early examples include the evaluation of the effect of lighting on productivity by the National Research Council during the 1920s, as well as the various studies at the Hawthorne Works of the Western Electric Company ${ }^{2}$. The benefit of an experiment is that it solves the endogeneity problem through randomization. This permits the identification of incentive effects using simple, 
unrestricted, statistical techniques (Burtless, 1995). Yet, the results observed within the experiment are specific to the experimental setting and may not generalize to settings outside of the experiment (Heckman and Smith, 1995).

Of interest in the personnel policy context is the ability to predict the effect of a permanent change in the contract on worker performance. Much criticism of experiments has concentrated on the Hawthorne effect - the fact that the experiment may present the worker with an artificial environment which alters his/her behaviour. Yet experimental results may fail to generalize for other reasons as well. In particular, since the experiment presents the worker with a short term, exogenous, change in his/her compensation system, the active incentives may be different from those introduced by a permanent change in the compensation system. As such, the results of the experiment will not generalize, even for a given set of workers and conditions.

This paper uses recent examples of empirical work on incentives to highlight the benefits and limitations of the experimental approach. I argue that the limited ability of experiments to identify the effects of a permanent change in contracts on worker performance provides a role for the application of behavioural models to experimental data.

\section{Endogenous Compensation Policies and Experiments}

One possible method for estimating incentive effects is to gather field data on worker productivity in which the contract varies. Exploiting this natural variation in the contract can identify responses as long as this variation is uncorrelated with unobserved factors affecting worker performance. Lazear (2000) uses such an approach in measuring the effect of a change from fixed wages to piece rates in the compensation system at the Safelite Glass Corporation. Yet, such exogenous variation is rare; economic studies suggest that compensation systems are correlated with factors both observable (Goldin 1986, Brown 1990) and unobservable (Paarsch and Shearer, 1999, Haley forthcoming) to the econometrician. While one might hope to eliminate problems of endogeneity by conditioning on observable factors, success depends on the econometrician possessing the same information as the firm.

One particularly clear example of endogenous compensation policies comes from the tree-planting industry of British Columbia where firms choose contracts on the basis of planting conditions. The tree-planting industry has many advantages as an environment in which to study incentive and contracting issues. Productivity is easily observable and contracts vary within firms. What is more, the contracts and work environment are very simple, allowing the straightforward study of incentives. For example, individuals are typically paid on the basis of individual productivity and unions are not present in the industry.

Planting is simple yet physically exhausting work. The productivity of the planters is determined by their effort level as well as the conditions of the terrain 
on which they are planting. For example, if the ground is hard and rocky or covered in underbrush, it takes more time and effort to plant a given number of trees properly, reducing daily worker productivity. In general, planting conditions vary a great deal. Some sites have been prepared for planting, meaning that the underbrush and slash timber has been removed (often by burning the site). Other sites are unprepared and are therefore more difficult to plant.

Piece rates reward quantity at the expense of quality (Stiglitz, 1975). When conditions render the planting of trees extremely difficult, workers have a tendency to shirk on quality in order to increase earnings; in response, firms switch to fixed wages to reduce perverse incentives. As such, sample data on worker productivity under piece rates and fixed wages contains a selection bias; fixed wages are paid under conditions which would give rise to low productivity anyway. The observed difference in productivity is made up of an incentive effect (the effect of the contract on worker behaviour) and the selection effect (the difference in conditions which caused the firm to choose the compensation system). Paarsch and Shearer (2000) used a structural econometric model to control for the unobserved planting conditions causing the selection bias. They found that while workers were $60 \%$ more productive under piece rates than fixed wages, only a $22.6 \%$ increase in productivity could be attributed to incentives - the rest was due to differences in conditions.

A more direct approach to solving the endogeneity problem is to perform a field experiment. Shearer (forthcoming) analyzed data from one such experiment conducted within a tree-planting firm. An experimental setting permits the compensation system to be varied exogenously, allowing direct measurement of the incentive effect without recourse to the identifying assumptions needed in structural models. The experiment was conducted within a firm that usually pays its workers piece rates. During the experiment, the payment system was changed to fixed wages. Since a worker's productivity is a function of his effort level and the planting conditions on the terrain he/she is planting, measuring the behavioral (incentive) effect required changing the compensation system while holding planting conditions constant.

The experiment was conducted with nine male participants, randomly selected from the firm. These planters were then randomly allocated to plant under fixed wages and piece rates under homogeneous planting conditions. Workers were randomly assigned to an area of land and informed of their compensation system before work began. After one half of the experiment was completed, the worker's compensation system was switched. Each worker involved in the experiment was, therefore, observed planting an equal number of days under both piece rates and fixed wages. In total the experiment provided 120 observations on daily productivity (60 under each compensation system). The experimental data show a $20 \%$ increase in productivity when workers are paid piece rates rather than fixed wages.

Such an experiment represents a short term, exogenous, change in a worker's 
compensation system; in this case, to fixed wages. At the end of the experiment the worker returns to the habitual payment system; here, piece rates. The experimental incentive effect thus measures the worker's response to this personnel policy and the incentives therein. For a forward looking worker, these incentives are not necessarily equivalent to the incentives of a permanent change in the compensation system the experimental effect will generalize to the permanent effect only under special circumstances.

\section{Field Experiments and Generalizability}

Much concern over the generalizability of experimental results has focused on the artificial environment in which experiments take place and how that affects participant behaviour. French (1953) advocated field experiments as a means of overcoming this difficulty. Since the experiment is performed within the firm, the results should be a good predictor of the effect of a permanent adoption of the policies applied during the experiment. Yet, field experiments can be tainted by artificial environments as well. One example is the Hawthorne effect. If workers know they are taking part in an experiment, they may alter their behaviour independent of the experimental treatment. The consequence may be a once and for all change in worker behaviour within the experimental setting - workers may become more conscientious under the perceived increased surveillance of the experiment. Alternatively, worker reaction to the treatment may be altered. Some of the early interpretations of the original Hawthorne experiments concluded that participants reacted positively to any change in the various treatments due to the special environment created by the test room (Gillespie, 1991). It is noteworthy, however, that Jones (1992) found no statistical evidence to support these claims. ${ }^{3}$

The easiest way to avoid Hawthorne effects is to keep workers ignorant of the fact that they are participating in an experiment. This requires a convincing explanation to the workers as to why the policy has changed and may place restrictions on the types of policies that can be investigated. ${ }^{4}$ However, the absence of Hawthorne effects does not guarantee the generalizability of the experimental results. One potential problem arises if workers self select across firms according to compensation systems. Under such circumstances, a permanent change in the compensation system may change the average quality of worker in the firm, although randomization within the firm will still estimate the effect of the treatment on the treated. ${ }^{5}$ Perhaps more fundamentally the experiment may be subject to Terminal Bias (Ferrall, 2002). The short-term nature of the experiment implies that the performance incentives within the experiment may differ from those following a permanent change in firm policy. As such, workers may react differently under fixed wages within an experiment than following a permanent change to fixed wages.

Theoretical models of effort determination under fixed wages generate incentives 
through termination contracts - the worker is fired if his/her performance falls below some standard set by the firm (Shapiro and Stiglitz 1984, Macleod and Malcolmson 1989). Incentives are provided through the presence of a benefit (or surplus) to the worker of continuing his relationship with the firm.

Consider the following simple example which treats the experiment as lasting one period within a stationary environment. For a forward looking worker, the value of providing an effort level sufficient to be retained within the firm is given by

$$
V^{N S}=\tilde{W}-C(E)+\beta V^{P R}
$$

where $\tilde{W}$ is the experimental fixed wage, $C(E)$ is the cost of effort, $\beta$ is the discount factor, and $V^{P R}$ is the value of piece-rate planting. The value of shirking is given by

$$
V^{S}=\tilde{W}+\delta \beta V^{F}+(1-\delta) \beta V^{P R}
$$

where $\delta$ is the probability that a substandard level of effort is detected and $V^{F}$ is the value of being fired. Assuming that firms enforce the maximum effort level workers are willing to supply given the future rents, fixed wage effort can be written

$$
\tilde{E}=C^{-1}\left(\delta \beta\left(V^{P R}-V^{F}\right)\right) .
$$

Experimental effort is independent of the fixed wage since the future surplus is generated under piece rates. ${ }^{6}$

After a permanent switch to fixed wages, the future rent that enforces effort must be generated under the fixed wage. The cost of effort to the firm is given by the no-shirking condition

$$
W=\frac{(1-\beta+\delta \beta)}{\delta \beta} C(E)+(1-\beta) V^{F}
$$

Using (3.1) the no-shirking condition can be written as

$$
C(E)-C(\tilde{E})=\frac{\delta \beta}{1-\beta+\delta \beta}\left[\mathcal{R}^{F W}(W \mid E=\tilde{E})-\mathcal{R}^{P R}\right]
$$

where $\mathcal{R}^{P R}=(1-\beta) V^{P R}-\bar{u}$ denotes the one period rent earned under piece-rate planting and $\mathcal{R}^{F W}(W \mid E=\tilde{E})=W-C(\tilde{E})-\bar{u}$ denotes the rent generated under fixed wage planting by a given wage if the worker supplies the same level of effort observed in the experiment.

It is clear from (3.2) that a permanent implementation of the fixed wage policy investigated in the experiment will not, in general, give rise to the same effort levels (or incentive effect) observed in the experiment. This, due to the fact that the level 
of wages paid in the experiment will not necessarily generate the same level of rents as those generating effort within the experiment.

A necessary condition for the experimental results to generalize to a permanent change in firm policy is for the fixed wage paid in the experiment to generate the same level of rents as piece rates; i.e.,

$$
\tilde{W}-C(\tilde{E})=(1-\beta) V^{P R} \text {. }
$$

In general, (3.2), gives a mapping from wages (rents) to effort levels which is a function of underlying preference parameters and outside opportunities. Predicting incentive effects after a permanent change to fixed wages requires estimating these parameters.

\section{Conclusions}

Personnel policy experiments provide economists with rich sample variation that permits the measurement of worker reaction to changes in contracts in a simple and direct manner. Yet, observed reactions depend on individual preferences, outside opportunities, as well as the personnel policy of the firm. Different policies will imply different reactions - there is no single incentive effect. The experiment gives us information on the reaction to a particular policy change; in the present example, a temporary switch from piece rates to fixed wages. As such, it is perhaps encouraging that the results of Shearer (forthcoming) accord closely to those of Paarsch and Shearer (1999) who estimated an incentive effect of $22.6 \%$ using data on temporary (but non experimental) changes to fixed wages. It is perhaps more puzzling that the results accord closely with those of Lazear (2000) who estimated an incentive effect of $22 \%$ using data from a permanent change in the compensation system. ${ }^{7}$ This might suggest that the distinction between permanent and temporary changes is unimportant. Yet, the true counterfactual is not observed. Lazear's study took place within a different labour market. ${ }^{8}$ The fact that the results are similar does not imply that a permanent change in compensation systems within the tree-planting industry would give results similar to those observed in the short-term experiment.

The presence of such unobserved counterfactuals provides a role for behavioural models in generalizing experimental results. While the unrestricted statistical analysis of experimental data can tell us what happened after the particular policy change observed within the experiment, it cannot, in general, tell us what will happen after other possible changes, including a permanent change in policy that replicates the short term experiment. As such, experimental data is better thought of as providing exogenous variation with which to identify structural models rather than as a tool for identifying incentive effects. 


\section{References}

Blinder, A. 1990. Paying for Productivity: A Look at the Evidence, Washington, The Brookings Institution.

Brown, C., 1990. "Firms' Choice of Method of Pay." Industrial and Labor Relations Review, 43(3): 165s-182s.

Brown, C., 1992. "Wage Levels and Method of Pay." Rand Journal of Economics, $23(3)$ : 366-375.

Burtless, G., 1995. "The Case for Randomized Field Trails in Economic and Policy Research." Journal of Economic Perspectives, 9(2): 63-84.

Chiappori, P.A. and B. Salanié, 2000. "Testing Contract Theory: A Survey of Some Recent Work." Mimeo, Department of Economics University of Chicago.

Copeland, A. and C. Monet, 2002. "The Welfare Effects of Incentive Schemes," Mimeo, University of Minnesota.

Ehrenberg, R. 1990. "Do Compensation Policies Matter?" Industrial and Labor Relations Review, Special Issue 43(3).

Ehrenberg, R. and R. Smith, 2000. Modern Labor Economics, Addison Wesley, New York.

Ferrall, C., 2002 "Estimation and Inference in Social Experiments" Mimeo, Queen's University.

Ferrall, C. and B. Shearer, 1999. "Incentives and Transaction Costs within the Firm: Estimating an Agency Model Using Payroll Records." Review of Economic Studies, 66(2): 309-338.

French, J. 1953. "Experiments in Field Settings." in Research Methods in the Behavioral Sciences, Festinger, L. and D. Katz, eds. New York: Holt, Rinehart \& Winston, pp. 98-135.

Gibbons, R., 1987. "Piece-Rate Incentive Schemes." Journal of Labour Economics, 5: 413-429.

Gillespie, R. 1991. Manufacturing Knowledge: A History of the Hawthorne Experiments. New York: Cambridge University Press.

Goldin, C. 1986. "Monitoring Costs and Occupational Segregation by Sex: A Historical Analysis." Journal of Labor Economics, 4(1): 1-27. 
Haley, M. forthcoming. "The Response of Worker Effort to Piece Rates: Evidence from the Midwest Logging Industry." Journal of Human Resources.

Hart, O. and B. Holmstrom. 1987. "The Theory of Contracts." In Advances in Economic Theory Fifth World Congress, ed. by T. Bewley. Cambridge, United Kingdom: Cambridge University Press.

Heckman, J. and J. Smith, 1995. "Assessing the Case for Social Experiments." Journal of Economic Perspectives, 9(2): 85-110.

Jones, S. 1992. "Was There a Hawthorne Effect?" American Journal of Sociology, 98, 3 (Nov., 1992): 451-468.

Lazear, E. 1986. "Salaries and Piece Rates." Journal of Business, 59(3): 405-31.

Lazear, E. 1998. Personnel Economics for Managers John Wiley \& Sons, New York.

Lazear, E. 2000. "Performance Pay and Productivity," American Economic Review, 90(5): 1346-1361.

Macho-Stadler, I. and J. D. Pérez-Castrillo 2001. An Introduction to the Economics of Information: Incentives and Contracts, Oxford.

MacLeod, W. and J. Malcomson. 1989. "Implicit Contracts, Incentive Compatibility, and Involuntary Unemployment." Econometrica, 57(2): 447-480.

Milgrom, P. and J. Roberts. 1992. Economics, Organization and Management. Englewood Cliffs, New Jersey: Prentice Hall.

Paarsch, H. and B. Shearer. 1999. "The Response of Worker Effort to Piece Rates: Evidence from the British Columbia Tree-Planting Industry." Journal of Human Resources Fall, 34(4): 643-667.

Paarsch, H. and B. Shearer. 2000. "Piece Rates, Fixed Wages, and Incentive Effects: Statistical Evidence from Payroll Records." International Economic Review February, 41(1): 59-92.

Parent, D. 1999. "Method of Pay and Earnings: A Longitudinal Analysis." Industrial and Labor Relations Review.

Pencavel, J. 1977. "Work Effort, On-the-Job Screening, and Alternative Methods of Remuneration." In Research in Labor Economics, Volume 1, ed. by R. Ehrenberg. Greenwich, Connecticut: JAI Press.

Salanié, B. 1994. Théorie des Contrats Economica, Paris. 
Shapiro, C. and J. Stiglitz. 1984. "Equilibrium Unemployment as a Worker Discipline Device." American Economic Review, 74(3): 433-444.

Seiler, E. 1984. "Piece Rate vs. Time Rate: The Effect of Incentives on Earnings." Review of Economics and Statistics, 66(3): 363-376.

Shearer, B. forthcoming. "Piece Rates, Fixed Wages, and Incentives: Evidence from a Field Experiment." Review of Economic Studies.

Stiglitz, J. 1975. "Incentives, Risk, and Information: Notes Towards a Theory of Hierarchy." Bell Journal of Economics 6(2): 552-79. 


\section{Endnotes}

1. For a recent survey of the econometrics of contracts see Chiappori and Salanié, 2000.

2. For an historical perspective of these experiments, see Gillespie, 1991.

3. A series of early experiments into the effects of different illumination levels on worker productivity at the Hawthorne plant allegedly produced such results. However, no data has survived from these experiments. Jones analysed data from subsequent experiments also conducted at the Hawthorne plant.

4. In the tree-planting experiment workers were told that contractual problems had arisen and that the price the firm was to receive per tree planted was undetermined. As a consequence the firm decided to pay its workers fixed wages. Contractual problems of this sort arise occasionally throughout the planting season and the payment of fixed wages is a normal response of the firm in question.

5. Lazear, 2000, found significant turnover took place at Safelite following a change from fixed wages to piece rates.

6. Paarsch and Shearer (1999) calculate the rents that piece-rate workers earn within a tree-planting firm.

7. The Safelite firm switched from fixed wages to piece rates. A strict interpretation of Lazear's results within the present framework implies considering the fixed wage as being a permanent policy; that is, one must consider the change in compensation system as a surprise to the workers.

8. For example, Lazear's data are from the mid 1990s when the unemployment rate in the United States was in the 5-6\% range (Ehrenberg and Smith, 2000). In contrast, the unemployment rate was in the $8-9 \%$ range in British Columbia in the mid-late 1990s, (http://www.bcstats.gov.bc.ca) when Shearer's study was completed. 